\title{
DAYA SAING DAN SENSITIVITAS USAHATANI JAGUNG DI KABUPATEN PACITAN
}

\author{
Lorenta In Haryanto, Masyhuri, dan Irham \\ Fakultas Pertanian, Universitas Gadjah Mada \\ Email: lorenta.inharyanto@gmail.com
}

\begin{abstract}
Strengthening competitiveness is an important factor in facing the growth of international trade in commodity markets, especially for maize as feed commodities. This research aims to: (1) analyze the level of profit and competitiveness of maize farming, (2) investigate farming components affecting competitiveness, and (3) analyze sensitivity level of profit and competitiveness towards the changes. Data were processed using PAM (Policy Analysis Matrix) and sensitivity analysis. The research was conducted on MarchMay 2018 in Pacitan with 102 maize farmers as sample respondents, collected proportionally. Sensitivity analysis observed four changes, i.e; increase of purchase price, the structure of labor, optimization of maize productivity, and weakening of rupiah exchange rate. Research findings indicated that (1) maize farming in Pacitan does not generate either financial or economic profits, as well as competitiveness, as shown by PCR and DRCR accounting for 1,033 and 1,024 respectively; (2) the component influencing competitive advantages is purchase price and component influencing comparative advantages is rupiah exchange rate; components simultaneously influencing both advantages are structure of labor and maize productivity; (3) the sensitivity analysis proves that the changes of profit are elastic towards the changes of four components indicated by elasticity indicator with a value of more than one. The changes of competitiveness are elastic only for purchase price, but for other components they are inelastic.
\end{abstract}

Keywords: Comparative advantages; Competitive advantages; Competitiveness; Maize; sensitivity.

\begin{abstract}
ABSTRAK
Penguatan daya saing merupakan faktor penting dalam menghadapi maraknya perdagangan global pada pasar komoditas, khususnya untuk komoditas jagung pakan. Penelitian ini bertujuan untuk (1) menganalisis tingkat keuntungan dan daya saing usahatani jagung, (2) mengetahui komponen usahatani yang mempengaruhi daya saing jagung, serta (3) menganalisis tingkat sensitivitas perubahan keuntungan dan daya saing akibat perubahan komponen dalam usahatani. Data diolah dengan metode PAM (Policy Analysis Matrix) dan analisis sensitivitas. Penelitian dilaksanakan dari bulan Maret 2018 sampai dengan Mei 2018 di Kabupaten Pacitan dengan 102 petani jagung sebagai sampel responden. Analisis sensitivitas meliputi empat perubahan yaitu peningkatan harga jual, perubahan struktur tenaga kerja manusia, peningkatan produktivitas jagung, serta pelemahan nilai tukar rupiah. Hasil penelitian menunjukkan bahwa (1) usahatani jagung di Kabupaten Pacitan tidak menguntungkan secara finansial dan ekonomi serta tidak berdaya saing, dengan nilai PCR dan DRCR masing-masing adalah1,033 dan 1,024. (2) Komponen yang mempengaruhi keunggulan kompetitif adalah harga jual, komponen yang mempengaruhi keunggulan komparatif adalah nilai tukar, sedangkan komponen yang mempengaruhi keunggulan kompetitif dan komparatif secara simultan adalah tenaga kerja dan produktivitas jagung; (3) Analisis sensitivitas menunjukkan bahwa perubahan keuntungan usahatani bersifat elastis terhadap perubahan keempat komponen, dengan nilai indikator elastisitas di atas satu. Perubahan daya saing usahatani jagung bersifat elastis terhadap harga jual, dan bersifat inelastis terhadap komponen lain.
\end{abstract}

Kata kunci: Daya saing; Jagung; Keunggulan komparatif; Keunggulan kompetitif; Sensitivitas. 


\section{PENGANTAR}

Peningkatan daya saing menjadi agenda utama pemerintah dalam menghadapi perdagangan bebas. Tantangan peningkatan daya saing adalah semakin maraknya produk impor dalam negeri sebagai alternatif penghematan (efisiensi) biaya pada produksi jagung. Dalam menghadapi tantangan tersebut, diperlukan pemahaman konsep dan pengukuran kinerja daya saing, diantaranya keunggulan kompetitif dan keunggulan komparatif. Keunggulan kompetitif mengacu pada efisiensi produksi usahatani dalam mencapai daya saing di tingkat internasional, sedangkan keunggulan komparatif mengacu pada perbandingan keuntungan bagi pengembangan komoditas di bawah kondisi perubahan seperti kebijakan pemerintah dan distorsi pasar.

Salah satu komoditas pertanian yang saat ini menjadi sasaran peningkatan daya saing adalah jagung. Jagung banyak dimanfaatkan sebagai komoditas pakan ternak dibandingkan konsumsi (pangan). Jagung merupakan komoditas yang memperoleh perlindungan pemerintah, antara lain melalui pemberlakuan tarif impor jagung, sebesar 5 persen, berdasarkan Peraturan Menteri Keuangan Nomor 6/ PMK.010/2017 mengenai Penetapan Tarif Bea Masuk atas Barang Impor, serta kuota impor melalui Peraturan Menteri Perdagangan Nomor 21 Tahun 2018 tentang Ketentuan Impor Jagung.

Tujuan dari perlindungan tersebut adalah meningkatkan produksi dalam negeri dan daya saing jagung, namun demikian, sampai saat ini Indonesia masih menjadi net importir jagung. Pada tahun 2015, produksi jagung di Indonesia mencapai 19,61 juta ton, sedangkan konsumsinya sebesar 5,03 juta ton, volume impor sebesar 3,5 juta ton, dan volume ekspor sebesar 0,25 juta ton. Nilai produksi yang tinggi dan penyerapan konsumsi jagung lokal yang rendah disebabkan oleh terbatasnya ketersediaan jagung dan rendahnya kualitas jagung dalam negeri. Penanganan pasca panen yang buruk juga menyebabkan kualitas jagung dibawah standar aturan untuk dijadikan pakan ternak. Pemerintah terus menggalakkan program pendampingan agar petani mengikuti acuan budidaya yang baik, salah satunya melalui program UPSUS PAJALE. Program tersebut bukan hanya bertujuan meningkatkan kualitas jagung namun juga meningkatkan produksi jagung sehingga masalah ketersediaan jagung dapat diatasi.

Salah satu bentuk kegiatan UPSUS PAJALE dalam menjamin ketersediaan jagung adalah pemanfaatan lahan bukansawah untuk penanaman jagung di sepanjang musim. Usahatani jagung dapat dilaksanakan dengan memanfaatan lahan sub-optimal, seperti lahan kering/tegalan, lahan gambut, dan lahan rawa pasang surut (Nurwahidah et al., 2015; Sutoro, 2015; Taufik et al., 2015; Tahir, 2017). Pemanfaatan lahan kering juga difokuskan pemerintah dalam rangka mengejar ketertinggalan pembangunan pertanian lahan kering dikarenakan terbatasnya lahan sawah untuk sumber produksi pertanian.

Kabupaten Pacitan memiliki lahan kering mencapai 90 persen dari luas wilayahnya. Lahan kering di Kabupaten Pacitan memiliki potensi dalam pengusahaan jagung (Lalu dan Syuryawati, 2017). Sebagian besar lahan tegalan ditanami komoditas jagung, khususnya jagung pakan. Kabupaten Pacitan memproduksi jagung pada 3 musim, yaitu Musim Penghujan I (Oktober-Januari), Musim Penghujan II (Februari- Mei), dan Musim Kemarau (JuniSeptember). Ketersediaan jagung di Kabupaten Pacitan berfluktuasi selama tahun 2011 sampai 2017, menyebabkan harga yang diterima petani juga fluktuatif. Dalam mengatasi fluktuasi harga tersebut, pemerintah mengeluarkan Peraturan Menteri Perdagangan Nomor 27/M-DAG/PER/5/2017 mengenai harga acuan pembelian di tingkat petani.

Biaya produksi yang tinggi juga menjadi penyebab adanya fluktuasi harga, sehingga pemerintah mengeluarkan beberapa kebijakan protektif diantaranya pembebasan tarif impor benih jagung melalui Peraturan Menteri Keuangan Nomor 6/PMK.010/2017, pengaturan pupuk bersubsidi melalui Peraturan Menteri Pertanian Nomor 59/Tahun 2016 dan Peraturan Menteri Perdagangan Nomor 155/M-DAG/PER/4/2013, serta pengaturan harga eceran BBM bersubsidi melalui 
Keputusan Menteri ESDM Nomor 3448 K/12/ MEM/2017. Kebijakan pemerintah mungkin saja memberikan dampak positif atau dampak negatif terhadap usahatani jagung. Kebijakan pemerintah dinilai efektif apabila menghasilkan keuntungan bagi usahatani jagung, namun jika terjadi sebaliknya maka diindikasikan bahwa usahatani jagung pada daerah tersebut sudah tidak memiliki daya saing.

Daya saing dipahami sebagai konsep yang statis, sehingga dibutuhkan analisis yang bersifat dinamis untuk mengantisipasi kecenderungan perubahan dan merumuskan kebijakan yang efektif. Perubahan yang terjadi pada usahatani jagung dapat disebabkan oleh perubahan harga output, upah tenaga kerja, nilai tukar rupiah, dan produkifitas. Faktorfaktor tesebut menyebabkan perubahan keuntungan yang turut berpengaruh terhadap perubahan daya saing. Tingkat kepekaan pada faktor yang diteliti dapat diukur menggunakan analisis sensitivitas.

Penelitian ini bertujuan untuk 1) menganalisis tingkat keuntungan dan daya saing usahatani jagung secara umum di Kabupaten Pacitan, 2) mengetahui komponen usahatani yang mempengaruhi daya saing jagung di Kabupaten Pacitan, serta 3) menganalisis tingkat sensitivitas perubahan keuntungan dan daya saing akibat perubahan komponen pada usahatani jagung di Kabupaten Pacitan.

\section{Daya saing}

Daya saing suatu komoditas dapat diukur melalui dua pendekatan, yaitu tingkat keuntungan dan tingkat efisiensi usahatani. Penelitian Suryana dan Agustian (2014) menyebutkan bahwa usahatani jagung memberikan keuntungan secara ekonomi dan sosial. Usahatani jagung juga layak diusahakan pada lahan suboptimal. Nurwahidah dkk. (2015) dan Taufik dkk. (2015) menunjukkan bahwa usahatani jagung di lahan kering layak diusahakan. Pendapatan usahatani jagung bervariasi bukan hanya antar daerah namun antarmusim. Rusastra (2004) menyebutkan bahwa usahatani jagung di musim kemarau pertama (MK I) menujukkan kelayakan ekonomi yang lebih baik dibanding musim kemarau II (MK II).

Efisiensi usahatani diukur berdasarkan keunggulan komparatif dan keunggulan kompetitif. Menurut Monke dan Pearson (1989), keunggulan komparatif mengukur efisiensi usahatani berdasarkan analisis ekonomi dengan memakai harga bayangan atau harga sosial, sedangkan keunggulan kompetitif diukur menggunakan harga privat. Indikator keunggulan komparatif adalah Domestic Resource Cost Ratio (DRCR), sedangkan indikator keunggulan kompetitif adalah Private Cost Ratio (PCR). Berdasarkan hasil kajian sebelumnya, komoditas jagung di Indonesia memiliki keunggulan komparatif dan kompetitif dengan nilai DRCR dan PCR yang masing-masing kurang dari satu Rusastra (2014); Suryana dan Agustian (2014).

\section{Sensitivitas}

Uji sensitivitas dilakukan dengan menelaah faktor yang memberikan pengaruh signifikan terhadap daya saing usahatani jagung. Hasil penelitian Agustian dan Hartoyo (2012), Rahman dkk. (2016), Suryana dan Agustian (2014) dan Suryani dkk. (2015) menunjukkan elastisitas penawaran output terhadap harga output bertanda positif dan elastis, sedangkan terhadap harga input (kecuali upah tenaga kerja) bertanda negatif dan inelastis. Variabel lain yang berpengaruh terhadap daya saing jagung adalah nilai tukar rupiah (Wanto, 2012) dan produktivitas (Aldila $d k k$., 2017).

\section{Lokasi Pengambilan Data}

Penelitian dilaksanakan di Kabupaten Pacitan. Pemilihan lokasi dilakukan secara sengaja dengan pertimbangan bahwa daerah tersebut merupakan daerah marginal yang memproduksi jagung hampir di sepanjang musim. Sampel Kecamatan yang diambil adalah Kecamatan Donorojo dan Kecamatan Pringkuku dengan pertimbangan bahwa secara akumulatif kecamatan tersebut memiliki pola tanam sepanjang tahun, dan menunjukkan produksi tertinggi dibandingkan kecamatan lainnya. Rumus Slovin digunakan dalam pembagian sampel: 


$$
n=\frac{N}{1+N e^{2}}
$$

Pada rumus ini, $N$ adalah ukuran populasi, $n$ adalah sampel, dan $e$ adalah tingkat presisi. Jumlah petani jagung di kedua kecamatan tersebut adalah 18.160 orang, sehingga dengan tingkat presisi sebesar 10 persen maka jumlah sampel responden adalah 102 petani jagung. Selanjutnya pembagian sampel responden dilakukan secara proporsional di setiap kecamatan, sehingga didapatkan sebaran sampel responden di Kecamatan Donorojo sejumlah 47 responden dan di Kecamatan Pringkuku sejumlah 55 responden. Penelitian dilaksanakan pada bulan Maret 2018 sampai dengan Mei 2018. Data penelitian terdiri dari data primer dan data sekunder. Data primer diperoleh dari hasil wawancara dengan para petani jagung, pedagang pengumpul (desa dan kecamatan) dan penyuluh Dinas Pertanian Kabupaten Pacitan, sedangkan data sekunder didapatkan melalui studi literatur dari jurnal, buku, dan internet.

\section{Analisis Data}

Analisis daya saing mengacu pada analisis usahatani dengan perhitungan Total biaya (TC) =TEC+TIC; dengan TC adalah Total Cost (Total Biaya; Rp), TEC adalah Total Explicity Cost (Total Biaya Eksplisit; Rp) dan TIC = Total Implicit Cost (Total Biaya Implisit; Rp). Analisis daya saing pada usahatani jagung menggunakan metode Policy Analysis Matrix (PAM). Tahapan dalam analisis PAM adalah (1) penentuan input dan output usahatani jagung, (2) alokasi komponen biaya menjadi biaya tradable (asing) dan non tradable (domestik), (3) penentuan harga bayangan, (4) tabulasi dalam matriks PAM (Tabel 1).

Tabel 1.

Tabulasi Matriks Analisis Kebijakan (PAM)

\begin{tabular}{lllcll}
\hline \multirow{2}{*}{ Uraian } & \multirow{2}{*}{ Penerimaan } & \multicolumn{2}{c}{ Biaya input } & Keuntungan \\
\cline { 3 - 5 } & & A & Tradable & Non tradable & \\
\hline Harga Privat & E & F & C & D \\
Harga Sosial & I & G & H \\
Efek Divergensi & J & K & L \\
\hline
\end{tabular}

Sumber : Monke dan Pearson (1989)

Keterangan:

Keuntungan Privat $(D)=A-(B+C)$

Keuntungan Sosial $(H)=E-(F+G)$

Rasio Biaya Privat $(P C R)=C /(A-B)$

Rasio Biaya Sumberdaya Domestik

$(\mathrm{DRCR})=\mathrm{G} /(\mathrm{E}-\mathrm{F})$

Transfer Output $(\mathrm{I})=\mathrm{A}-\mathrm{E}$

Koefisien Proteksi Output Nominal (NPCO) $=$ A / E

Transfer Input Tradable $(\mathrm{J})=\mathrm{B}-\mathrm{F}$

Transfer Input Non Tradable $(\mathrm{K})=\mathrm{C}-\mathrm{G}$

Koefisien Proteksi Input Nominal $(\mathrm{NPCl})=\mathrm{B} / \mathrm{F}$

Transfer Bersih $(\mathrm{L})=\mathrm{D}-\mathrm{H}$

Koefisien Proteksi Efektif $(E P C)=(A-B) /(E-F)$

Rasio Subsidi Bagi Produsen (SRP) $=\mathrm{L} / \mathrm{E}$

Input yang digunakan pada usahatani jagung terdiri dari luas lahan (hektar), bobot benih jagung (kilogram), volume pupuk kimia (kilogram), volume pupuk organik (kilogram atau liter), volume pestisida (kilogram atau liter), peralatan/mesin usahatani yang dihitung dari nilai penyusutan (Rp), kebutuhan bahan bakar minyak (liter), dan jumlah tenaga kerja yang terdiri dari Tenaga Kerja Dalam Keluarga dan Tenaga Kerja Luar Keluarga
(HOK). Output usahatani berupa bobot jagung pipilan (kilogram). Alokasi biaya produksi menggunakan pendekatan total dengan menghitung persentase jumlah pemenuhan total atas kebutuhan input di dalam negeri yang dipenuhi dari pasar domestik dan pasar asing (impor) (Monke dan Pearson, 1989). Input terdiri dari input tradable dan input non tradable. Input tradable merupakan input yang dapat diperdagangkan secara internasional dan sebaliknya untuk input non-tradable.

Presentase alokasi biaya input mengacu pada jumlah impor dan produksi domestik terhadap jumlah kebutuhan berdasarkan data dari BPS, APPI, dan sumber lainnya. Penentuan harga bayangan ditentukan berdasarkan pendekatan harga. Pada kelompok yang dominan ekspor harga bayangan mengacu pada harga FOB (Free on Board) dan pada kelompok yang dominan impor harga bayangan mengacu 
pada harga CIF (Cost Insurance Freight), sedangkan untuk kelompok yang disewa dan hanya diproduksi secara domestik digunakan pendekatan nilai riil.

Analisis sensitivitas diterapkan pada dua sisi yaitu sensitivitas keuntungan dan sensitivitas indikator daya saing. Sensitivitas atau elastisitas perubahan diukur mengunakan rumus berikut:

$$
\mathrm{Ep}, \mathrm{c}=\frac{P_{1}}{Q_{1}} \times \frac{Q_{1}-Q_{0}}{P_{1}-P_{0}}
$$

Ep,c adalah elastisitas keuntungan atau indikator daya saing, adalah nilai awal faktor, adalah nilai akhir faktor (setelah perubahan), adalah nilai awal keuntungan atau indikator daya saing, adalah nilai akhir keuntungan atau indikator daya saing (setelah perubahan).

\section{PEMBAHASAN}

\section{Gambaran Umum Lokasi Penelitian}

Berdasarkan hasil observasi lapang, sebagian besar petani jagung berada pada usia produktif berkisar antara 40-49 tahun dan berpengalaman dalam menanam jagung selama 11-20 tahun, sedangkan tingkat pendidikan yang dimiliki secara dominan adalah SMP. Petani menanam jagung pada musim penghujan I (Oktober-Januari), musim penghujan II (Februari-Mei), dan musim kemarau (June-September). Rata-rata luas lahan penanaman jagung untuk musim penghujan I, penghujan II, dan kemarau masing-masing sebesar 0,122 hektar, 0,155 hektar, dan 0,125 hektar per petani.
Sistem irigasi pada musim penghujan adalah tadah hujan, sedangkan sistem irigasi pada musim kemarau adalah semi teknis melalui pompa yang disewa. Sebagian besar petani mengusahakan jagung sebanyak dua kali dalam setahun yaitu pada musim penghujan I dan musim penghujan II ( 28,43 persen) atau sekali dalam setahun selama musim penghujan I (26,47 persen). Sebagian besar petani menjual seluruh hasil panen, namun beberapa petani mengambil sebagian (sebanyak 15 persen) hasil panen untuk konsumsi rumah tangga. Hal tersebut menggambarkan bahwa komoditas jagung di Kabupaten Pacitan belum diusahakan secara komersiil.

\section{Keuntungan Finansial dan Keuntungan Ekonomi Usahatani Jagung}

Pada analisis usahatani, penghasilan petani ditentukan berdasarkan nilai keuntungan dan bukan nilai pendapatan, yang artinya biaya implisit usahatani turut dipertimbangkan (data selengkapnya pada Lampiran 1 dan Lampiran 2) Biaya implisit pada Tabel 2 meliputi biaya Tenaga Kerja Dalam Keluarga (TKDK), biaya pupuk kandang (termasuk dalam kategori pupuk organik), dan biaya modal (termasuk dalam kategori biaya lain-lain). TKDK terdiri dari istri dan anak yang merupakan tenaga tanpa keahlian khusus (Unskilled Labor) dan tanpa dibayar, pupuk kandang diproduksi sendiri dari hasil ternak petani, dan bunga modal merupakan biaya imbangan meskipun dalam usahataninya petani tidak melakukan peminjaman biaya modal.

Tabel 2.

Biaya Usahatani Jagung berdasarkan Analisis Pendapatan dan Analisis Keuntungan per Hektar di Kabupaten Pacitan, Tahun 2017

\begin{tabular}{lllll}
\hline \multirow{2}{*}{\multicolumn{1}{c}{ Biaya Input }} & \multicolumn{2}{c}{ Analisis Pendapatan } & \multicolumn{2}{c}{ Analisis Keuntungan } \\
\cline { 2 - 5 } & \multicolumn{1}{c}{ Nilai Privat } & \multicolumn{1}{c}{ Nilai Sosial } & Nilai Privat & Nilai Sosial \\
\hline Benih & 1.108 .581 & 723.099 & 1.108 .581 & 723.099 \\
Pupuk Anorganik & 2.150 .305 & 4.171 .283 & 2.150 .305 & 4.171 .283 \\
Pupuk Organk & 2.319 .748 & 2.319 .748 & 229.274 & 229.274 \\
Insektisida & 136.646 & 136.646 & 136.646 & 136.646 \\
Herbisida & 280.687 & 256.653 & 280.687 & 256.653 \\
Tenaga Kerja Luar Keluarga & 1.205 .043 & 1.194 .720 & 1.205 .043 & 1.194 .720 \\
Tenaga Kerja Dalam Keluarga & 6.596 .459 & 6.548 .143 & 0 & 0
\end{tabular}


Lanjutan Tabel 2

\begin{tabular}{lllll}
\hline \multirow{2}{*}{\multicolumn{1}{c}{ Biaya Input }} & \multicolumn{2}{c}{ Analisis Pendapatan } & \multicolumn{2}{c}{ Analisis Keuntungan } \\
\cline { 2 - 5 } & \multicolumn{1}{c}{ Nilai Privat } & \multicolumn{1}{c}{ Nilai Sosial } & Nilai Privat & Nilai Sosial \\
\hline Tenaga Kerja Mesin & 625.677 & 625.677 & 625.677 & 625.677 \\
Biaya lain-lain & 2.830 .440 & 3.351 .977 & 2.567 .279 & 2.503 .830 \\
\hline Total Biaya & 17.253 .589 & 19.327 .949 & 8.303 .494 & 9.841 .185 \\
\hline
\end{tabular}

Sumber: Data Primer (2018).

Tabel 3.

Keuntungan Privat dan Keuntungan Sosial Usahatani Jagung per Hektar di Kabupaten Pacitan, Tahun 2017

\begin{tabular}{|c|c|c|c|c|}
\hline Nilai & Penerimaan (Rp/Ha) & Biaya $(\mathrm{Rp})$ & Keuntungan (Rp) & Pendapatan (Rp/Ha) \\
\hline Privat & 16.727 .545 & 17.253.589 & -526.044 & 8.424 .051 \\
\hline Sosial & 18.904 .273 & 19.327.949 & -423.676 & 9.063 .088 \\
\hline
\end{tabular}

Sumber: Data Primer (2018).

Berdasarkan hasil analisis pendapatan pada Tabel 2 dan Tabel 3 usahatani jagung di Kabupaten Pacitan menghasilkan surplus. Nilai penghasilan dari usahatani jagung relatif tinggi sebesar $\mathrm{Rp} 8,4$ juta perhektar permusim tanam, dengan catatan nilai analisis tersebut tidak menyertakan biaya implisit. Biaya implisit merupakan bagian dari konsep biaya kesempatan (opportunity cost), yang menjelaskan bahwa secara obyektif peluang yang diambil untuk usahatani memberikan keuntungan finansial dan ekonomi, sehingga analisis keuntungan digunakan dalam peneltian ini.

Keuntungan finansial atau keuntungan privat usahatani jagung diukur berdasarkan harga aktual input dan output, sedangkan keuntungan ekonomi atau keuntungan sosial diukur berdasarkan harga bayangan dengan mengabaikan adanya distorsi pasar dan intervensi pemerintah. Berdasarkan analisis keuntungan pada Tabel 3, usahatani jagung tidak menguntungkan baik secara privat maupun sosial dengan kerugian masing-masing sebesar Rp526.044,00 perhektar dan Rp 423.676 per hektar. Nilai tersebut menggambarkan bahwa biaya (impisit dan eksplisit) usahatani jagung di Kabupaten Pacitan lebih tinggi dibandingkan penerimaan petani. Hal ini tidak sebanding dengan penelitian Nurwahidah $d k k$ (2015) dan Taufik $d k k$. (2015). Dengan mengambil sampel lokasi di Sumatera Utara dan Sumbawa, kedua peneliti menyatakan usahatani jagung pada lahan kering masih memberikan keuntungan. Perbedaan pada hasil penelitian disebabkan perbedaan jumlah biaya input pada lokasi penelitian. Penggunaan input seperti pupuk dan tenaga kerja (HOK) di Sumatera Utara dan Sumbawa cenderung sangat rendah, sedangkan di Kabupaten Pacitan, faktor tenaga kerja menyumbang nilai yang sangat tinggi dalam usahatani.

Kerugian petani, secara privat maupun sosial, disebabkan oleh rendahnya produktivitas jagung dan rendahnya harga jagung, mengakibatkan rendahnya penerimaan petani. Produktivitas jagung di Kabupaten Pacitan sebesar 54,52 kuintal perhektar, cenderung rendah dibandingkan dengan wilayah sekitarnya seperti Ponorogo dan Wonogiri yang masing-masing sebesar 66,88 kuintal perhektar dan 61,44 kuintal perhektar. Di samping hal tersebut, harga jual yang diterima petani di Kabupaten Pacitan baik dilihat secara privat maupun sosial, yaitu sebesar Rp3.068 perhektar dan Rp3.467 perhektar, ternyata lebih rendah dibandingkan harga jual di Ponorogo dan Wonogiri yang rata-rata adalah sebesar Rp3.600,00 perhektar.

\section{Daya saing Usahatani Jagung}

Daya saing jagung diukur menggunakan pendekatan keunggulan kompetitif dan keunggulan komparatif. Keunggulan kompetitif 
menunjukkan sejauhmana usahatani jagung mampu membiayai faktor domestik pada tingkat harga privat, dengan menggunakan indikator Private Cost Ratio (PCR). Jika nilai PCR kurang dari satu maka komoditas tersebut memiliki keunggulan kompetitif. Hasil analisis PAM pada Tabel 4 menunjukkan bahwa usahatani jagung di Kabupaten Pacitan tidak memiliki keunggulan kompetitif. Nilai PCR sebesar 1,033 mengindikasikan bahwa untuk mendapatkan nilai tambah output jagung sebesar Rp1 diperlukan tambahan biaya domestik lebih besar sebesar Rp1,033, sehingga memproduksi jagung di dalam negeri tidak lebih efisien dibandingkan mengimpor jagung.

Tabel 4.

Alokasi Biaya Input Tradable dan Non Tradable Usahatani Jagung per Hektar di Kabupaten

Pacitan

\begin{tabular}{lllll}
\hline \multirow{2}{*}{ Komponen Input } & \multicolumn{3}{c}{ Nilai Privat } & \multicolumn{2}{c}{ Non Tradable } & Tradable \\
\cline { 2 - 5 } Nenih & 1.107 .251 & 1.330 & 722.231 & 868 \\
Pupuk Urea & 875.775 & 10.189 & 1.581 .023 & 18.393 \\
Pupuk SP-36 & 156.115 & 123.611 & 280.188 & 221.851 \\
Pupuk NPK & 903.889 & 48.576 & 1.918 .146 & 103.083 \\
Pupuk ZA & 26.192 & 5.957 & 39.595 & 9.006 \\
Pupuk Kompos & 117.888 & 0 & 117.888 & 0 \\
Pupuk Kandang & 2.090 .474 & 0 & 2.090 .474 & 0 \\
Pupuk Organik & 111.375 & 11 & 111.375 & 11 \\
Insektisida & 84.680 & 51.967 & 84.680 & 51.967 \\
Herbisida & 173.942 & 106.745 & 159.048 & 97.605 \\
TKLK & 1.205 .044 & 0 & 1.194 .720 & 0 \\
TKDK & 6.596 .459 & 0 & 6.548 .142 & 0 \\
TK Mesin & 250.271 & 375.406 & 250.271 & 375.406 \\
Bahan Bakar & 22.857 & 8.135 & 42.915 & 15.275 \\
Sewa lahan & 1.135 .025 & 0 & 1.135 .025 & 0 \\
Sewa pompa & 687.089 & 0 & 687.089 & 0 \\
Penyusutan Alat & 708.031 & 6.142 & 618.165 & 5.362 \\
Bunga Modal & 236.231 & 26.930 & 679.984 & 77.517 \\
\hline Total Biaya & 16.488 .589 & 765.000 & 18.350 .826 & 977.123 \\
\hline PCR & 1,033 & & & \\
DRCR & 1,024 & & & \\
\hline
\end{tabular}

Sumber: Data Primer. 2018.

Indikator lain dalam menentukan daya saing adalah keunggulan komparatif. Keunggulan komparatif mencerminkan efisiensi penggunaan sumberdaya domestik menggunakan indikator Domestic Resource Cost Ratio (DRCR). Nilai DRCR yang lebih dari satu (yaitu 1,024) mengimplikasikan bahwa usahatani jagung di Kabupaten Pacitan tidak memiliki keunggulan komparatif. Nilai DRCR mengimplikasikan bahwa setiap \$1 yang dikeluarkan untuk mengimpor jagung, setara dengan mengeluarkan biaya domestik sebesar
\$1,024 jika memproduksi jagung dalam negeri. Analisis indikator PCR dan DRC lebih jelas dapat dilihat pada Tabel 4.

Berdasarkan Tabel 4, usahatani jagung di Kabupaten Pacitan tidak memiliki daya saing. Daya saing erat kaitannya dengan nilai penerimaan (Tabel 3) terhadap biaya input tradable dan input non-tradable. Biaya input tradable dan non tradable yang lebih tinggi dari nilai penerimaan menyebabkan PCR dan DRCR bernilai lebih dari satu. Hasil tersebut berbeda dengan penelitian Suryana dan Agustian 
(2014) yang menyatakan usahatani jagung di Indonesia masih memiliki keunggulan komparatif dan kompetitif. Perbedaan hasil tersebut dikarenakan lokasi yang diteliti oleh peneliti tersebut bukan merupakan daerah non marginal seperti di Kabupaten Pacitan. Meskipun demikian, penelitian sebelumnya menyebutkan bahwa nilai PCR dan DRCR dapat berubah seiring adanya perubahan yang terjadi pada komponen usahatani. Perubahan tersebut memberikan peluang untuk menciptakan lingkungan yang lebih kondusif bagi usahatani, sehingga usahatani jagung di Kabupaten Pacitan dapat menghasilkan keuntungan dan daya saing.

\section{Pengaruh Perubahan Komponen Usahatani serta Tingkat Kepekaan Keuntungan dan Daya Saing Jagung Akibat Perubahan Komponen}

Breierova dan Choudhari

mengemukakan bahwa analisis sensitivitas digunakan untuk menentukan bagaimana tingkat kepekaan suatu model terhadap perubahan nilai-nilai parameternya. Terdapat banyak kemungkinan kejadian di masa depan yang dapat mengubah hasil analisis PAM, sehingga analisis sensitivitas dibatasi hanya pada kemungkinan perubahan yang memiliki pengaruh besar terhadap hasil analisis (Suhardedi et al. (2017). Pengujian sensitivitas dilakukan dengan menelaah faktor yang memberikan pengaruh signifikan terhadap daya saing jagung. Hasil penelitian sebelumnya (Agustian dan Hartoyo, 2012; Suryana dan Agustian, 2014; Suryani et al., 2015; Rahman et al., 2016) menunjukkan elastisitas penawaran output terhadap harga output bertanda positif dan bersifat elastis, sedangkan terhadap harga input (kecuali upah tenaga kerja) bertanda negatif dan bersifat inelastis. Variabel lain yang berpengaruh terhadap daya saing jagung adalah nilai tukar rupiah (Wanto, 2012) dan produktivitas (Aldila et al., 2017). Analisis sensitivitas dilakukan pada empat komponen tersebut yaitu harga output, biaya tenaga kerja, nilai tukar rupiah, dan produkifitas jagung.

Penentuan kenaikan harga output jagung pada skenario pertama didasarkan pada Peraturan Menteri Perdagangan Nomor 27/M-DAG/PER/5/2017, yang menetapkan harga acuan jagung dengan kadar air 15 persen adalah Rp 3.150 per kilogram. Pada skenario kedua, penurunan penggunaan tenaga kerja berdasarkan pertimbangan bahwa penggunaan tenaga mesin yang belum optimal menyebabkan petani menanggung biaya tenaga kerja yang tinggi, sehingga dilakukan alternatif penggantian tenaga manusia menjadi tenaga mesin. Penggunaan tenaga mesin ditujukan pada kegiatan pengolahan lahan karena petani memiliki alternatif untuk mengganti penggunaan tenaga kerja manusia (menjadi nol) menjadi tenaga mesin (Panjaitan et al., 2017). Pada skenario ketiga, nilai tukar rupiah diubah menjadi Rp 14.107 per \$. Nilai tersebut merupakan nilai tukar rupiah pada pertengahan bulan Mei 2018, yang merupakan nilai terlemah selama Juni 2016-Juni 2018. Pada skenario keempat, diasumsikan benih bantuan yang diberikan pemerintah mampu memberikan hasil panen mencapai 6,9 ton perhektar, yaitu nilai rata-rata produktivitas jagung di lahan marginal (Ekasingh dkk, 2001). Hasil analisis perubahan keuntungan, indikator daya saing dan elastisitas usahatani jagung dilihat pada Tabel 5 .

Tabel 5 menunjukkan bahwa skenario (3) merupakan skenario terbaik dalam peningkatan daya saing. Usahatani pada skenario (3) menghasilkan keuntungan privat dan sosial yang lebih tinggi dibandingkan skenario lainnya. Selain itu, skenario (3) menunjukkan tingkat daya saing jagung yang terbaik, dengan indikator keunggulan kompetitif (PCR) dan indikator keunggulan komparatif (DRCR) yang lebih kecil dibandingkan skenario lainnya. Nilai PCR pada skenario (3) sebesar 0,808 menunjukkan bahwa untuk meningkatkan nilai tambah output sebesar Rp 1 pada harga privat, maka usahatani jagung di Kabupaten Pacitan mengeluarkan tambahan biaya domestik lebih kecil yaitu Rp0,808. Nilai DRCR sebesar 0,800 menunjukkan bahwa dengan penerapan skenario tiga maka setiap \$1,00 yang dibutuhkan untuk mengimpor jagung, hanya dibutuhkan biaya domestik sebesar \$ 0,800 untuk memproduksi jagung di Kabupaten 
Pacitan, dengan kata lain, penerapan skenario ini memberikan masukan bagi pemerintah untuk tidak mengimpor jagung dikarenakan biaya produksi lebih efisien ketika usahatani jagung dikerjakan secara domestik.

Tabel 5.

Perubahan Keuntungan, Indikator Daya saing dan Elastisitas Usahatani Jagung per Hektar di Kabupaten Pacitan, Tahun 2017

\begin{tabular}{llllllllll}
\hline \multicolumn{1}{c}{ Skenario } & \multicolumn{2}{c}{$\begin{array}{c}\text { Perubahan } \\
\text { Keuntungan }\end{array}$} & \multicolumn{2}{c}{$\begin{array}{c}\text { Elastisitas } \\
\text { Keuntungan }\end{array}$} & \multicolumn{2}{c}{$\begin{array}{c}\text { Perubahan } \\
\text { Indikator Daya } \\
\text { saing }\end{array}$} & $\begin{array}{c}\text { Elastisitas Daya } \\
\text { saing }\end{array}$ \\
\cline { 2 - 10 } & \multicolumn{1}{c}{ Privat } & Sosial & Privat & Sosial & PCR & DRCR & PCR & DRCR \\
\hline (1) Harga aktual & -77.492 & -423.676 & $-31,80$ & 0,00 & 1,005 & 1,024 & $-1,02$ & 0,00 \\
(2) Tenaga Kerja & -413.506 & -320.197 & 2,69 & 3,31 & 1,027 & 1,018 & 0,08 & 0,07 \\
(3) Produktivitas & 3.913 .804 & 4.593 .922 & $-31,80$ & $-44,62$ & 0,808 & 0,800 & $-0,82$ & $-0,82$ \\
(4) Nilai Tukar & -526.044 & 197.241 & 0,00 & $-31,03$ & 1,033 & 0,989 & 0,00 & $-0,71$ \\
\hline
\end{tabular}

Sumber: Data Primer (2018).

Berdasarkan Tabel 5, semua skenario menyebabkan perubahan keuntungan dan indikator daya saing. Pada skenario (1), perubahan harga aktual menyebabkan nilai kerugian awal usahatani jagung mengalami penurunan, namun masih belum memberikan keuntungan (nilai kerugian sebesar Rp 77.492 per hektar). Hal serupa terjadi pada skenario (2) yaitu perubahan upah tenaga kerja dan skenario (4) yaitu perubahan nilai tukar. Perubahan keuntungan pada semua skenario diikuti oleh perubahan daya saing. Skenario (1) mengakibatkan adanya perubahan pada indikator keunggulan kompetitif, skenario (2) dan skenario (3) mengakibatkan adanya perubahan pada keunggulan kompetitif sekaligus keunggulan komparatif, dan skenario (4) menyebabkan perubahan hanya pada keunggulan komparatif.

Perubahan keuntungan dan daya saing dianggap bersifat elastis apabila secara mutlak nilai elastisitas lebih dari 1, dan bersifat inelastis ketika sebaliknya. Hasil analisis pada Tabel 5 menunjukkan bahwa perubahan keuntungan bersifat elastis terhadap perubahan harga aktual, biaya tenaga kerja, produktivitas, dan nilai tukar. Perubahan daya saing bersifat elastis terhadap perubahan harga aktual namun bersifat inelastis terhadap perubahan biaya tenaga kerja, produktivitas, dan nilai tukar.

Secara garis besar, semakin tinggi nilai elastisitas maka dampak dari perubahan yang terjadi akan semakin besar dibandingkan perubahan pada skenario yang bersifat inelastis. Perubahan terbesar adalah pada skenario (1) yang menunjukkan bahwa peningkatan Rp1harga aktual menyebabkan penurunan kerugian sebesar Rp31,80, dan peningkatan keunggulan kompetitif usahatani jagung sebesar 1,02 satuan. Meskipun demikian, skenario (1) hanya memberikan

Tabel 6.

Analisis Pendapatan Jagung per Hektar di Kabupaten Pacitan

\begin{tabular}{llllccc}
\hline \multicolumn{1}{c}{ Uraian } & Satuan & Jumlah & Harga Privat & Nilai Privat & Harga Sosial & Nilai Sosial \\
\hline & & & $(\mathbf{R p})$ & $(\mathbf{R p})$ & $(\mathbf{R p})$ & $\mathbf{( R p )}$ \\
\hline $\begin{array}{l}\text { A. Produksi } \\
\text { B. Input }\end{array}$ & $\mathrm{Kg}$ & $5.452,73$ & 3.068 & 16.727 .545 & 3.467 & 18.904 .273 \\
Benih & $\mathrm{Kg}$ & 17,51 & 63.318 & 1.108 .581 & 41.301 & 723.099 \\
Pupuk Urea & $\mathrm{Kg}$ & 445,87 & 1.987 & 885.964 & 3.587 & 1.599 .416 \\
Pupuk SP-36 & $\mathrm{Kg}$ & 125,46 & 2.230 & 279.726 & 4.002 & 502.038 \\
Pupuk NPK & $\mathrm{Kg}$ & 375,93 & 2.534 & 952.465 & 5.377 & 2.021 .229 \\
Pupuk ZA & $\mathrm{Kg}$ & 19,89 & 1.617 & 32.150 & 2.444 & 48.600
\end{tabular}


Lanjutan Tabel 6

\begin{tabular}{|c|c|c|c|c|c|c|}
\hline Uraian & Satuan & Jumlah & Harga Privat & Nilai Privat & Harga Sosial & Nilai Sosial \\
\hline & & & (Rp) & $(\mathbf{R p})$ & $(\mathbf{R p})$ & (Rp) \\
\hline Pupuk Kompos & $\mathrm{Kg}$ & 282,93 & 417 & 117.888 & 417 & 117.888 \\
\hline Pupuk Kandang & $\mathrm{Kg}$ & $4.180,95$ & 0 & 0 & 0 & 0 \\
\hline Pupuk Organik Cair 1 & $\mathrm{Lt}$ & 128,29 & 750 & 96.220 & 750 & 96.220 \\
\hline Pupuk Organik Cair 2 & $\mathrm{Lt}$ & 0,15 & 100.000 & 15.166 & 100.000 & 15.166 \\
\hline Insektisida (cair) & Lt & 0,34 & 107.750 & 36.833 & 107.750 & 36.833 \\
\hline Insektisida (granul) & $\mathrm{Kg}$ & 3,87 & 25.817 & 99.813 & 25.817 & 99.813 \\
\hline Herbisida 1 & $\mathrm{Lt}$ & 0,22 & 334.000 & 72.102 & 222.667 & 48.068 \\
\hline Herbisida 2 & $\mathrm{Lt}$ & 0,14 & 209.762 & 30.352 & 209.762 & 30.352 \\
\hline Herbisida 3 & $\mathrm{Lt}$ & 2,66 & 65.271 & 173.808 & 65.271 & 173.808 \\
\hline Herbisida (granul) & $\mathrm{Kg}$ & 0,02 & 266.667 & 4.425 & 266.667 & 4.425 \\
\hline \multicolumn{7}{|l|}{ TKLK } \\
\hline Persiapan Lahan & HOK & 2,89 & 51.481 & 148.932 & 50.982 & 147.487 \\
\hline Penanaman & $\mathrm{HOK}$ & 4,38 & 50.611 & 221.820 & 50.120 & 219.669 \\
\hline Menyiangi & $\mathrm{HOK}$ & 6,69 & 48.266 & 322.755 & 47.798 & 319.624 \\
\hline Memupuk & $\mathrm{HOK}$ & 0,37 & 50.000 & 18.723 & 49.515 & 18.541 \\
\hline Mengendalikan Hama & $\mathrm{HOK}$ & 0,51 & 44.167 & 22.478 & 43.738 & 22.260 \\
\hline Memanen & HOK & 3,90 & 53.722 & 209.502 & 53.201 & 207.470 \\
\hline Merontok (pipil) & HOK & 1,66 & 46.667 & 77.329 & 46.214 & 76.579 \\
\hline Pasca Panen & HOK & 0,81 & 52.778 & 42.717 & 52.266 & 42.303 \\
\hline Pengangkutan & Paket & 1,69 & 83.333 & 140.787 & 83.333 & 140.787 \\
\hline \multicolumn{7}{|l|}{ TKDK } \\
\hline Persiapan Lahan & $\mathrm{HOK}$ & 15,70 & 0 & 0 & 0 & 0 \\
\hline Penanaman & HOK & 17,86 & 0 & 0 & 0 & 0 \\
\hline Menyiangi & HOK & 23,69 & 0 & 0 & 0 & 0 \\
\hline Memupuk & HOK & 10,93 & 0 & 0 & 0 & 0 \\
\hline Mengendalikan Hama & HOK & 4,38 & 0 & 0 & 0 & 0 \\
\hline Memanen & HOK & 19,28 & 0 & 0 & 0 & 0 \\
\hline Merontok (pipil) & $\mathrm{HOK}$ & 19,68 & 0 & 0 & 0 & 0 \\
\hline Mengeringkan & HOK & 16,01 & 0 & 0 & 0 & 0 \\
\hline Pasca Panen & $\mathrm{HOK}$ & 4,72 & 0 & 0 & 0 & 0 \\
\hline \multicolumn{7}{|l|}{ TK mesin } \\
\hline Persiapan Lahan & Paket & 1,86 & 257.778 & 479.633 & 257.778 & 479.633 \\
\hline Merontok (pipil) & Paket & 0,56 & 262.500 & 146.044 & 262.500 & 146.044 \\
\hline Bahan Bakar & Lt & 5,70 & 5.433 & 30.992 & 10.200 & 58.189 \\
\hline Sewa lahan & Musim & 1,00 & 1.135 .025 & 1.135 .025 & 1.135 .025 & 1.135 .025 \\
\hline Sewa pompa & Paket & 0,33 & 2.061 .268 & 687.089 & 2.061.268 & 687.089 \\
\hline Penyusutan Alat & Unit & 1,00 & 714.173 & 714.173 & 623.527 & 623.527 \\
\hline Bunga Modal & Musim & 1,00 & 0 & 0 & 0 & 0 \\
\hline Total Biaya (C) & $\mathrm{Rp}$ & & & 8.303 .494 & & 9.841 .185 \\
\hline Penerimaan (R) & $\mathrm{Rp}$ & & & 16.727 .545 & & 18.904 .273 \\
\hline Pendapatan & $\mathrm{Rp}$ & & & 8.424 .051 & & 9.063 .088 \\
\hline $\mathrm{R} / \mathrm{C}$ & & & & 2,015 & & 1,921 \\
\hline
\end{tabular}

Sumber: Data Primer. 2018. 
Tabel 7.

Analisis Usahatani Jagung perhektar di Kabupaten Pacitan

\begin{tabular}{|c|c|c|c|c|c|c|}
\hline Uraian & Satuan & Jumlah & Harga Privat & Nilai Privat & Harga Sosial & Nilai Sosial \\
\hline & & & (Rp) & (Rp) & (Rp) & (Rp) \\
\hline A. Produksi & $\mathrm{Kg}$ & $5.452,73$ & 3.068 & 16.727 .545 & 3.467 & 18.904 .273 \\
\hline \multicolumn{7}{|l|}{ B. Input } \\
\hline Benih & $\mathrm{Kg}$ & 17,51 & 63.318 & 1.108 .581 & 41.301 & 723.099 \\
\hline Pupuk Urea & $\mathrm{Kg}$ & 445,87 & 1.987 & 885.964 & 3.587 & 1.599 .416 \\
\hline Pupuk SP-36 & $\mathrm{Kg}$ & 125,46 & 2.230 & 279.726 & 4.002 & 502.038 \\
\hline Pupuk NPK & $\mathrm{Kg}$ & 375,93 & 2.534 & 952.465 & 5.377 & 2.021 .229 \\
\hline Pupuk ZA & $\mathrm{Kg}$ & 19,89 & 1.617 & 32.150 & 2.444 & 48.600 \\
\hline Pupuk Kompos & $\mathrm{Kg}$ & 282,93 & 417 & 117.888 & 417 & 117.888 \\
\hline Pupuk Kandang & $\mathrm{Kg}$ & $4.180,95$ & 500 & 2.090 .474 & 500 & 2.090 .474 \\
\hline Pupuk Organik Cair 1 & Lt & 128,29 & 750 & 96.220 & 750 & 96.220 \\
\hline Pupuk Organik Cair 2 & Lt & 0,15 & 100.000 & 15.166 & 100.000 & 15.166 \\
\hline Insektisida (cair) & Lt & 0,34 & 107.750 & 36.833 & 107.750 & 36.833 \\
\hline Insektisida (granul) & $\mathrm{Kg}$ & 3,87 & 25.817 & 99.813 & 25.817 & 99.813 \\
\hline Herbisida 1 & Lt & 0,22 & 334.000 & 72.102 & 222.667 & 48.068 \\
\hline Herbisida 2 & $\mathrm{Lt}$ & 0,14 & 209.762 & 30.352 & 209.762 & 30.352 \\
\hline Herbisida 3 & Lt & 2,66 & 65.271 & 173.808 & 65.271 & 173.808 \\
\hline Herbisida (granul) & $\mathrm{Kg}$ & 0,02 & 266.667 & 4.425 & 266.667 & 4.425 \\
\hline \multicolumn{7}{|l|}{ TKLK } \\
\hline Persiapan Lahan & HOK & 2,89 & 51.481 & 148.932 & 50.982 & 147.487 \\
\hline Penanaman & $\mathrm{HOK}$ & 4,38 & 50.611 & 221.820 & 50.120 & 219.669 \\
\hline Menyiangi & $\mathrm{HOK}$ & 6,69 & 48.266 & 322.755 & 47.798 & 319.624 \\
\hline Memupuk & $\mathrm{HOK}$ & 0,37 & 50.000 & 18.723 & 49.515 & 18.541 \\
\hline Kendali Hama & $\mathrm{HOK}$ & 0,51 & 44.167 & 22.478 & 43.738 & 22.260 \\
\hline Memanen & HOK & 3,90 & 53.722 & 209.502 & 53.201 & 207.470 \\
\hline Merontok (pipil) & $\mathrm{HOK}$ & 1,66 & 46.667 & 77.329 & 46.214 & 76.579 \\
\hline Pasca Panen & $\mathrm{HOK}$ & 0,81 & 52.778 & 42.717 & 52.266 & 42.303 \\
\hline Pengangkutan & Paket & 1,69 & 83.333 & 140.787 & 83.333 & 140.787 \\
\hline \multicolumn{7}{|l|}{ TKDK } \\
\hline Persiapan Lahan & $\mathrm{HOK}$ & 15,70 & 50.000 & 784.878 & 49.515 & 777.265 \\
\hline Penanaman & $\mathrm{HOK}$ & 17,86 & 49.778 & 889.002 & 49.515 & 884.309 \\
\hline Menyiangi & HOK & 23,69 & 48.028 & 1.137 .668 & 49.515 & 1.172 .897 \\
\hline Memupuk & $\mathrm{HOK}$ & 10,93 & 50.000 & 546.501 & 49.515 & 541.200 \\
\hline Kendali Hama & $\mathrm{HOK}$ & 4,38 & 47.778 & 209.171 & 49.515 & 216.776 \\
\hline Memanen & $\mathrm{HOK}$ & 19,28 & 52.722 & 1.016 .222 & 49.515 & 954.403 \\
\hline Merontok (pipil) & $\mathrm{HOK}$ & 19,68 & 48.333 & 951.307 & 49.515 & 974.565 \\
\hline Mengeringkan & $\mathrm{HOK}$ & 16,01 & 50.000 & 800.646 & 49.515 & 792.880 \\
\hline Pasca Panen & HOK & 4,72 & 55.278 & 261.064 & 49.515 & 233.848 \\
\hline \multicolumn{7}{|l|}{ TK mesin } \\
\hline Persiapan Lahan & Paket & 1,86 & 257.778 & 479.633 & 257.778 & 479.633 \\
\hline Merontok (pipil) & Paket & 0,56 & 262.500 & 146.044 & 262.500 & 146.044 \\
\hline Bahan Bakar & $\mathrm{Lt}$ & 5,70 & 5.433 & 30.992 & 10.200 & 58.189 \\
\hline
\end{tabular}




\begin{tabular}{|c|c|c|c|c|c|c|}
\hline Uraian & Satuan & Jumlah & Harga Privat & Nilai Privat & Harga Sosial & Nilai Sosial \\
\hline & & & (Rp) & (Rp) & (Rp) & (Rp) \\
\hline Sewa lahan & Musim & 1,00 & 1.135 .025 & 1.135 .025 & 1.135 .025 & 1.135 .025 \\
\hline Sewa pompa & Paket & 0,33 & 2.061 .268 & 687.089 & 2.061 .268 & 687.089 \\
\hline Penyusutan Alat & Unit & 1,00 & 714.173 & 714.173 & 623.527 & 714.173 \\
\hline Bunga Modal & Musim & 1,00 & 263.161 & 263.161 & 757.501 & 757.501 \\
\hline Total Biaya (C) & $\mathrm{Rp}$ & & & 17.253 .589 & & 19.327 .949 \\
\hline Penerimaan (R) & $\mathrm{Rp}$ & & & 16.727 .545 & & 18.904 .273 \\
\hline Keuntungan & $\mathrm{Rp}$ & & & -526.044 & & -423.676 \\
\hline $\mathrm{R} / \mathrm{C}$ & & & & 0,970 & & 0,978 \\
\hline
\end{tabular}

Sumber: Data Primer. 2018.

Dampak pada keunggulan kompetitif, dan tidak memberikan dampak pada keunggulan komparatif. Skenario (3) dianggap terbaik dikarenakan melalui perubahan pada satu komponen (yaitu produktifvitas) mampu memberikan perubahan terhadap kedua indikator daya saing, sehingga melalui peningkatan produktivitas, usahatani jagung di Kabupaten Pacitan bukan hanya menguntungkan secara finansial dan ekonomi, tetapi menghasilkan keunggulan komparatif dan kompetitif.

\section{SIMPULAN}

Usahatani jagung di Kabupaten Pacitan tidak menguntungkan baik secara finansial maupun ekonomi. Usahatani jagung di Kabupaten Pacitan tidak berdaya saing, baik dilihat dari sisi keunggulan kompetitif maupun keunggulan komparatif. Komponen usahatani yang mempengaruhi perubahan daya saing secara simultan adalah produktivitas dan tenaga kerja. Harga aktual hanya berpengaruh terhadap keunggulan kompetitif sedangkan nilai tukar hanya berpengaruh terhadap keunggulan komparatif usahatani jagung. Analisis sensitivitas menunjukkan bahwa perubahan keuntungan bersifat elastis terhadap perubahan harga aktual, biaya tenaga kerja, produktivitas, dan nilai tukar. Perubahan daya saing bersifat elastis terhadap perubahan harga aktual namun bersifat inelastis terhadap perubahan produktifitas, biaya tenaga kerja dan nilai tukar. Upaya-upaya teknis dalam peningkatan produktivitas merupakan hal yang menarik untuk selanjutnya diteliti, mengingat peningkatan daya saing erat kaitannya dengan produktivitas.

\section{Ucapan terimakasih}

Ucapan terima kasih disampaikan kepada Lembaga Pengelola Dana Pendidikan (LPDP) yang telah membiayai riset ini melalui Beasiswa Pendidikan Indonesia (BPI).

\section{DAFTAR PUSTAKA}

Agustian, A. dan Hartoyo, S. (2012) 'Pendugaan Elastisitas Penawaran Output dan Permintaan Input Usahatani Jagung', Jurnal Ekonomi Pembangunan, 13(2), pp. 247-259.

Aldila, H. F., Fariyanti, A. dan Tinaprilla, N. (2017) 'Daya Saing Bawang Merah di Wilayah Sentra Produksi di Indonesia', Jurnal Manajemen dan Agribisnis, 14(1), pp. 43-53. doi: 10.17358/jma.14.1.43.

Breierova, L. dan Choudhari, M. (1996) An Introduction to Sensitivity Analysis, Massachusetts Institute of Technology. Cambridge: Massachusetts Institute of Technology. doi: 10.1016/j. epsr.2009.03.004.

Ekasingh, B., Gypmantasiri, P. dan Thongngam, K. (2001) 'Maize Farming in Marginal Areas of Thailand: Evidence from the Fields, 2000', CIMMYT: Centro Internacional de 
Mejoramiento de Maíz y Trigo, 1(1), pp. 1-22.

Lalu, M. S. dan Syuryawati (2017) 'Faktorfaktor yang Mempengaruhi Usahatani Jagung di Lahan Sawah dan Lahan Kering', Balai Penelitian Tanaman Serelia, 20(1), pp. 81-90.

Monke, E. A. dan Pearson, S. R. (1989) The Policy Analysis Matrix For Agricultural Development. California: Cornell University Press Ithaca.

Nurwahidah, S. Darwanto, D. H., Masyhuri, dan Waluyati, L. R. (2015) ‘Efficiency and Competitiveness of Corn Farming in Sumbawa Regency', IOSR Journal of Agriculture and Veterinary Science Ver. I, 8(11), pp. 2319-2372. doi: 10.9790/2380-081113947.

Panjaitan, R. C. V., Maryani dan Husaini (2016) 'Komparatif Pemanfaatan Mekanisasi Pertanian Usahatani Padi di Desa Tabing Rimbah Kecamatan Mandastana Kabupaten Barito Kuala, Kalimantan Selatan', in Seminar Nasional Lahan Basah Tahun 2016. Banjarmasin: Universitas Lambung Mangkurat, pp. 200-204.

Rahman, S. Kazal, M. M. H., Begum, I. A., dan Alam, M. J. (2016) ‘Competitiveness, Profitability, Input Demand and Output Supply of Maize Production in Bangladesh', Agriculture, 6(2), p. 21. doi: 10.3390 /agriculture6020021.

Rusastra, I. W., B. Rachman, \& S. Friyatno. 2004. Analisis Daya Saing dan Stuktur Proteksi Komoditas Palawija, in Prodising Efisiensi dan Daya Saing Sistem Usahatani Beberapa Komoditas Pertanian di Lahan Sawah pp. 28-49.
Suhardedi, C., Darwanto, D. H. dan Irham (2017) 'Competitiveness Rice Farming in Sragen Regency', Agro Ekonomi, 28(1), pp. 19-31. doi: https://doi.org/10.22146/jae.24584.

Suryana, A. dan Agustian, A. (2014) 'Analisis Daya saing Usahatani Jagung di Indonesia', Analisis Kebijakan Pertanian, 12(2), pp. 143-156.

Suryani, E., Hartoyo, S., Sinaga, B. M., dan Sumaryanto, N. F. N. (2015) 'Pendugaan Elastisitas Penawaran Output dan Permintaan Input pada Usaha Tani Padi dan Jagung: Pendekatan MultiinputMultioutput', Agro Ekonomi, 33(2), pp. 91-106. doi: 10.21082/jae. v33n2.2015.91-106.

Sutoro (2015) 'Determinan Agronomis Produktivitas Jagung (The Agronomic Factors Determining Maize Productivity)', Iptek Tanaman Pangan, 10(1), pp. 39-46.

Tahir, A. G. (2017) 'Analisis Pendapatan Usahatani Jagung pada Lahan Sawah dan Tegalan di Kecamatan Ulaweng, Kabupaten Bone Sulawesi Selatan', Jurnal Galung Tropika, 6(1), pp. 1-11.

Taufik, M., Maintang dan Nappu, M. B. (2015) 'Kelayakan Usahatani Jagung di Sulawesi Selatan', Jurnal Pengkajian dan Pengembangan Teknologi Pertanian, 18(1), pp. 67-80.

Wanto, S. H. (2012) 'Analisis Daya Saing Kakao Indonesia', in Seminar Nasional $\mathcal{E}$ Temu Ilmiah Jaringan Peneliti. IAI Darussalam Blokagung Banyuwang, pp. 434-441. 